\title{
GAYATRI: Mistress behind Political Concept of Monarchy Throne for Democratic People in Majapahit Kingdom
}

\author{
Oktafia Kusuma Sari ${ }^{1)}$, Nanda Handaru Nichita ${ }^{2)}$, Dhiemas Fajar Victoriawan ${ }^{3)}$, \\ and Ahmad Naufal Azizi ${ }^{4)}$ \\ ${ }^{1,2,3,4}$ Departement of Politics and Government, Faculty of Social Science and Political Science, \\ Universitas Gadjah Mada, Indonesia
}

\begin{abstract}
There are missing pieces in the history of Indonesian Political Thinking. We are doing research to prove if it's true that political thinking of monarchy throne for democratic people, is a thought by Gayatri who is a mistress of Majapahit kingdom. Majapahit is one of the biggest kingdom in the history of Indonesia. The Kingdom itself covered almost every region of Southeast Asia, and become one of Asian biggest trade center of rice, spice, salt, and fabric during its golden age, fourteenth century. The most renowned story of Majapahit is Palapa Oath by Gajah Mada, a general (so called Mahapatih) of majapahit. The Oath stated that he would not enjoy any Palapa (worldly enjoyment) until Nusantara is united under the flag of Majapahit, which then they unite the Nusantara at Majapahit Golden Age ruled by Hayam Wuruk. Therefore, in order to learn who is behind this concept, we have to identify Gayatri's political concept. Gayatri is a woman who had great influence in Majapahit Kingdom due to her political thinking of Monarchy Throne for democratic people and her concept of uniting Nusantara. Our research is focusing on how Gayatri's political thinking influence the political system in Indonesia. On the other side, this research concludes the historical values in the story of Gayatri on emphasizing woman role as a mother and her concept about emancipation of women in Indonesia. This research is using qualitative descriptive method, with data collected using interview and literature review. Triangulation will be our analysis techniques.
\end{abstract}

Keywords: History, Woman emancipation, Political thinking

\section{Introduction}

The establishment of Republic Indonesia to become an independent and solid country from the Western Sumatera to the east end Papua with total areas approximately 1.9 million square kilometres can't be separated from the history that preceded it. The birth of Majapahit Kingdom at the end of the 13th century until the early 16th century had a significant role in making the concept of Unitary State of Indonesia that currently still being upheld (Coedes, 2010). According to the history, the Palapa Oath posed Mahapatih Gajah Mada in the struggle to unite the archipelago (Nusantara) -which is now called Indonesia-used by the first President of the Republic of Indonesia, Ir. Sukarno in determining and choosing the form of the State which matches the cultural character of the Republic Indonesia after independence in 1945. However, we should know that there was someone who had the key behind the thought of Gajah Mada to unite Nusantara.

She is Sri Rajendradewi Gayatri, the youngest child of Singasari's last king, Kertanegara and the mistress from the first king of Majapahit, Raden Wijaya. A woman behind the glory of Majapahit that have not been known by a lot of people, even the one studying history rarely know her. Someone who has a tender heart and blessed to have an intelligent mind beyond the common women at that time. Someone who thought that it was not only previous king's lineage that determine the position they deserve in the Kingdom, but even Shudra caste (very poor, born from a very low class) also should have an equal opportunity based on their individual capabilities. Gayatri Rajapatni, a woman that had been fighting the goals to unity Nusantara from her father 
Kertanegara -the last king of Singasari- to successfully pass it to her children and the peak of her success in her grandson Hayam Wuruk with Mahapatih Gajah Mada from the Sudra.

Briefly, this paper will discuss thoroughly how the background of Majapahit emerged. The figure of Gayatri, her role as a mistress of Raden Wijaya who successfully built and nurtured the character of the heirs that would inherit Majapahit Kingdom later wisely, also how a mistress of Majapahit political thought who without doubt have taught the concept of modern democracy under the tyranny of monarchy.

\section{The Fall of Singasari and The Birth of Majapahit}

The history of the emergence of Majapahit kingdom cannot be separated from the historical setting that came from the collapse of the empire Singasari attacks led by Jayakatwang from Kediri Kingdom. Raden Wijaya, commander of the Singasari kingdom and Kertanegara leaders who pursue Kediri troops to the north were forced to run away after hearing Singasari Kingdom was taken down and king Kartanegara was killed. Seeing these conditions, Raden Wijaya and his followers fled to Madura and met with Arya Wiraraja to ask for help at a time strategizing counterattack they would do.

With the advice of Arya Wiraraja, Raden Wijaya and his troops devoted themselves to Jayakatwang in Kediri, and by his request they were awarded a forest region called Tarik to become the region's defense of Kediri kingdom and named it Majapahit. This name came from Maja tree that tastes bitter, bitter in Javanese language is 'Pahit' so the kingdom was called Majapahit. However, behind this story, Raden Wijaya had planned to attacks from the inside of Kediri Kingdom. There was a long wait, until the momentum awaited by Raden Wijaya finally arrived. Mongol armies from China, led by Shih-Pi, Ike-Mise, and you Hsing come to Java to kill Kertanegara who has dared to spoil the face Meng Chi envoy Kaisar Kubhilai Khan (Endang, 2007). But Mongolian armies did not know that Kertanegara had been killed by Jayakatwang forces. This momentum was utilized by Raden Wijaya to turn back the attacks on the kingdom of Kediri. As the result of Raden Wijaya's provocation, Mongolian armies attacked Kediri kingdom and managed to kill Jayakatwang.

After Jayakatwang was killed, the Mongols feasted to celebrate his victory. This opportunity was also used by Raden Wijaya to turn against the Mongol army who had helped them and ultimately they retreat back to their country. Since that time, based on data from the Yuan Dynasty (1280-1367) Raden Wijaya ascended the throne in $1294 \mathrm{AD}$ with the title Sri Kertarajasa Jayawardhana. Book titled Pararaton and Negarakertagama also provide the same data. Pararaton reported that Raden Wijaya rose to the throne in 1216 S or 1294 AD. Similarly Negarakertagama are on the same data that is in the year 1294 AD. Raden Wijaya eventually married to four daughters. Among the four wives of Raden Wijaya, there is the one he loved the most, not his consort, but his mistress that always being underestimated in the royal palace. However, this is different mistress, she inherited her father's determination to unity the fragmented nusantara, this mistress has different ideas and concepts of women's age and her contemporaries. She holds Rajapatni title, and she is Gayatri Rajapatni: The mastermind behind the golden age of Majapahit. 


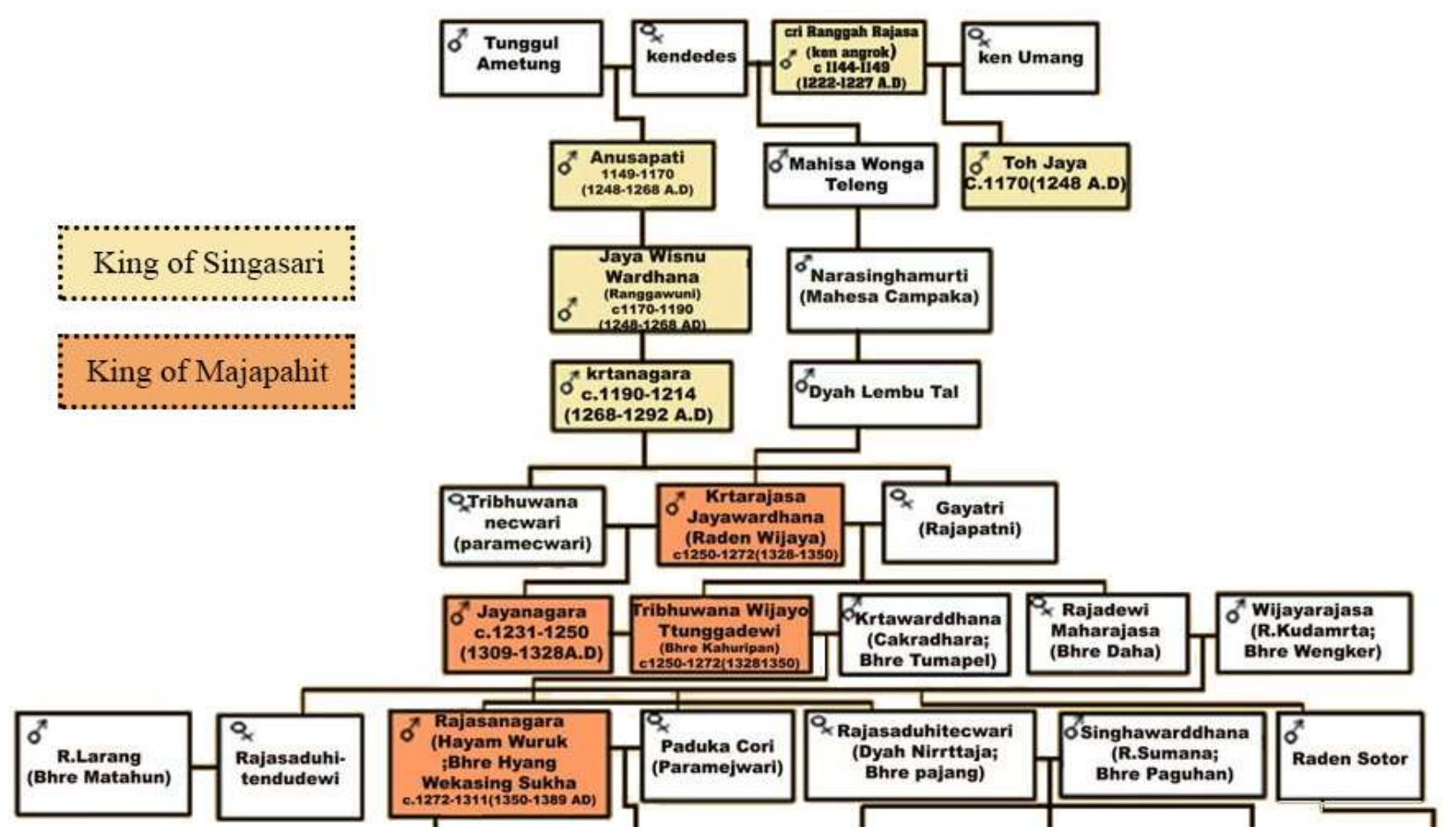

Fig. 1: Majapahit and Singasari Family Tree (Djafar, 2009)

\section{Figure of Gayatri Rajapatni}

Gayatri was born to be the last daughter of king Kertanegara in Singasari. Gayatri have three older sisters Tribhuwaneswari, Narendraduhita, and Jayendradewi . Gayatri is very different with her three sister, three of her sisters are very busy beautifying themselves in order to get attention from all of the bachelors who have interest to propose all of her sisters (Drake, 2012). Gayatri does not like to dress up and get those attentions. Instead, she is known to be boyish although she has beautiful face. Gayatri has more concerns on religion, kingdom, and governing people, more of all, she likes to learn something new. Undertand Gayatri's interest, her father Kertanegara gave Gayatri a teacher, who is also her father close friend and a very religious man. Besides having a teacher, Gayatri also loved to have discussion with his father. Although Gayatri is very eager to get more knowledge, she has a different side in which she loved theatrical act and all of the local actors. Kertanegara doesn't have a son, so in order to protect the Lineage of Kingdom thrones, inevitably Kartanegara had to marry off his daughters carefully. Gayatri's first sister Tribhuwana Necwari married to a prince named Wijaya. Her second sister, Mahadewi, also engaged to prince Ardaraja. All of Kartanegara daughters have to be married off with a prince, or nobles in order to protect the line of descendants of Kingdom throne.

According to the Pararaton book in 1292, there was an attack on Singasari by Kediri kingdom that led to the death of King Kertanegara whose legacy can be found in the form of statue so called 'candi' named Jawi Candi, it is located in Pasuruan, East Java. It is believed to be the late king Kertanegara ash storage. Meanwhile, Gayatri who survived from the attack was taken to Kediri by the help of her servant, by disguising as kingdom servant named Ratna Sutawan. All of the survivors that were not killed were moved to Daha, capital city of Kediri. In her hiding place in Kediri, Gayatri intentionally met her first sister husband, prince Wijaya. As the husband of the first royal daughter of Singasari, he took the obligation to seize its power back. Raden Wijaya is someone who is very handsome and very clever. During the discussion between Gayatri and prince Wijaya, Gayatri who had been interested in politics since she was a child and also an intelligent female figure contributed his thoughts to Wijaya. Gayatri even have a mission to unite all the land of Java. Since then Gayatri became interested in by 
Raden Wijaya and vice versa. Raden Wijaya eventually retook the area and established a kingdom named Majapahit. Raden Wijaya then married Gayatri as the fourth wife, where his first wife was the princess and also gayatri first older sister, and gayatri as a mistress. This action is a form of responsibility for the daughters of Singasari for assault Kediri devastating tragedy in Singasari. In the inscription of Palungan in 1330M written by Maharani Majapahit Tribhuwanatunggadewi, Dyah Gayatri stating that Gayatri Rajapatni given the title of which means "The companion of the King", because of his intelligence she managed to win the heart of Raden Wijaya, when in reality she was only the king fourth wife.

\title{
4. Political Thinking of Gayatri Rajapatni
}

Gayatri's way of thinking was very influenced by her interest in politics since she was a kid. Besides, she had a habit to discuss with her father when she was alive, that affected her way of critical thinking, especially about government affairs. Gayatri is one of the figures that had significant role in the early development of Majapahit, Gayatri with King Wijaya set the goals and plans in order to bring prosperity to the people. This text below is a piece of proof related to Gayatri's political and democratic thinking.

\begin{abstract}
..."Gayatri bequeathed some brilliant principles about the importance of understanding someone's personality, competition and old factions that had some conflicts and some different qualities as well that should be seen by a leader in defensive advice and guidance. Gayatri suggested to Wijaya so that he did not just relate this rebellion by considering the personality of his colleague. Gayatri thought that the rebellion which happened in the harbor was a complex (structural) problem. Wijaya agreed with Gayatri's statement since none of the advisory board of Wijaya rejected that argument. Finally, they agreed to assign an independent group that composed of Hinduism and Buddhist priest, and some officials that went to Tuban and talked to some people there. Then the group made a report about Tuban's people complains, aspirations and ideas and gave it to Majapahit slowly through the help from Gayatri. ... (Drake, 2012)
\end{abstract}

Political Analysis:

Democratic has the principles as a way or a medium to channel the aspirations from the powerless people to the in order to change or affect, at least, the policy to achieve prosperity for society. This is strengthened by the statement of Philippe C. Schmitter about democracy, he stated that a state in order to respond the needs and interests of its people, they have to be involved and participate in arranging and expressing their needs actively and freely. Not only clear understanding, but also have various sources as well as the desire to involve in political struggle that needed so that their preferences could become a consideration to the rulers or also tried to have a position in government (Schmitter, 1991).

Democracy relies heavily on political system in every government aspects. Easton theory explained that the existence of input, process, and output as a whole system of political system that cannot be separated. Input can be in the form of support or demand, then being processed by people or institution that have the authority until it produces output in the form of policy. 


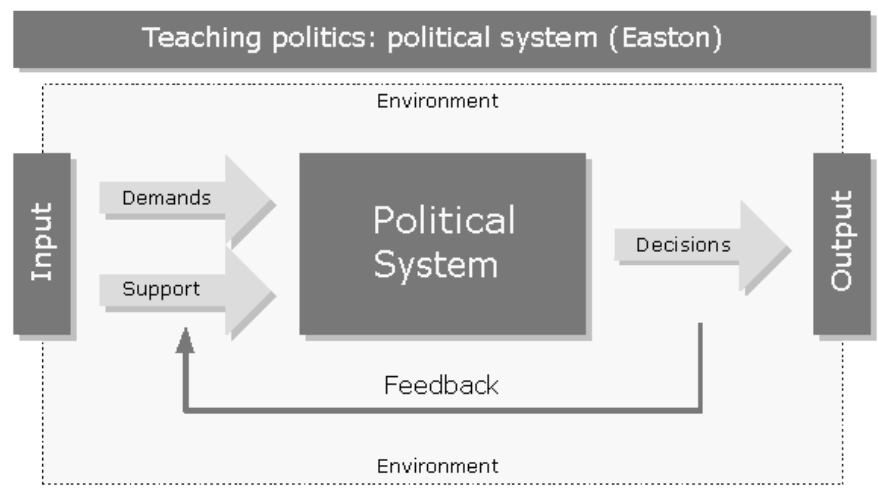

Fig. 2: David Easton Political System (Easton, 1953)

Phase of democracy in the time of Majapahit kingdom was different than democracy in modern era as we know it. In the story of rebellion in Tuban, Gayatri gave a consideration to the King Wijaya to open a channel to the people's aspirations in Tuban, by sending officials to come and ask his complaints to the public so that eventually the rebellion can be muted. According to Benedict Anderson on the power of Java (Anderson, 2006);

- Power does not spread or very centralized and unified into one place. There is a tendency ruling dictator / authoritarian.

- Sources of power that comes from trust (God) so that the legitimacy of the public has no effect on the continuity of the ruler.

- Power is constant

In this research the authors underline the point that the source of power is not derived from the legitimacy of the people. In the kingdom period a leader will indeed continue to have power without any party can impose including the people. Indirectly shows that the kingdom does not require any principle of democracy because power is absolute and it is contradictive. If we go back to the first principles that democracy is exist to influence policy as a means of legitimacy of the leader and the people.

In particular, the kingdom of Majapahit had discovered the finer points of democracy but because in the kingdom and today situation have different social and political conditions, that Cause the democracy in the kingdom cannot be said to be intact for the people because of peoples position that is not strong enough. In the end, we could say that the emergence of democracy has started since the kingdom even though its application has not been perfectly executed according to the concept of democracy that is now known by many people.

\section{Behind The Glorious Story of Gajah Mada}

Gajah Mada, known as mahapatih (or so called supreme general) of Majapahit who was capable to unite Nusantara under the flag of Majapahit Kingdom. Thus, legitimizing Majapahit as one of the Greatest Kingdom ever existed in Indonesia. The greatness of Mahapatih Gajahmada often told as a folklore, at classical literatures, theatre, and even adapted into a novel, films, comics, drama, and etc. Despite of his family background, coming from Shudra Caste (Lowest hierarchy in social life on Hindu teachings), Gajah Mada was still able to develop his military career.

Starting his career as a private, his skills and capability brought him to be king Jayanegara's head elite guardian called Bhayangkara. Then his career boosted as he succeeded protecting King Jayanegara from a big Rebellion by Kuti, Gajah Mada became General of Kahuripan (one of district in majapahit). From then, his task and duty is not all about protecting kingdom and its nobles. He needs to understand more about management of the kingdom, on making right and wise decision in many aspects and problem solving in the near future. This is 
the point where Gajah Mada starts being approached by Gayatri Rajapatni, who then changed his political view and act, then inspired him uniting Nusantara in a flag of Majapahit Kingdom.

Poor family background and lack of governing knowledge due to only receiving basic military education didn't prevent Gayatri to make Gajah Mada rethink about many things, including his loyalty to a corrupted king, Jayanegara. Gajah Mada used to think that there must be nothing bad happened to the ruler of the kingdom, and that was the best way to be the best patriot to protect the kingdom is by protecting the king. But then Gayatri taught him that humans must be true to themselves. Gayatri told Gajah Mada that if loyalty is given to a bad person, then the loyalty itself will be come to waste, because it's not given for a greater good. Gayatri started her teachings by making Gajah Mada asked himself, whether his loyalty was given to the right person. Then Gayatri continued her teaching on what should be done by a "good king", and what shouldn't. Gayatri used King Wijaya (Majapahit 1st Ruler) as a comparison to Jayanegara. Gayatri showed how much the difference in the governing action given by Wijaya, who's wise, calm, and listen to another perception in order to maintain nation stability. Then Gayatri showed that Jayanegara is the opposite of what should we call a "good king". Even though he's good at war and brave, Jayanegara was egoist, and unwise. And in the top of it, Jayanegara recognized himself as a manifest of vishnu, making him doesn't wanna listen to anyone anymore.

Gayatri teachings had so much influences on Gajah Mada political act and thought, including when the behavior of King Jayanegara was getting worse, with the indirect command from Gayatri, he planned to assassinate King Jayanegara without using his own hands, but using RA Tanca (one of the best Surgeon in majapahit) when the King is sick and need to be operated. Then on Tribhuwana Tunggadewi regime, Gajah Mada who's elected to be Mahapatih of Majapahit declared his controversial oath, Palapa Oath. In achieving his oath, and doing his job as mahapatih, once again Mahapatih Gajah Mada taught by Gayatri. Gajah Mada and Gayatri deep conversation began on what programs should be run, how to conquer a kingdom without using too much force, and how to acculturate different norms, religion, and cultures throughout the country. And in sort of ways, those strategy works. Even though, later on after Gayatri had passed away, there was a tragedy caused by Gajah Mada named "Perang Bubat". It's a Tragedy on Hayam Wuruk's Regime (4th Ruler \& Golden Age of Majapahit) when Gajah Mada deceived Sunda Kingdom using political marriage between Hayam Wuruk and Dyah Pitaloka (Sunda Kingdom Princess) then killed the whole marriage cavalcade from Sunda in a place named Bubat.

\section{Conclusion}

In the end, we come to the final conclusion that Gayatri Rajapatni, a woman from the youngest child of the last king of Singasari and Raden Wijaya's favorite mistress had a thought that steps ahead beyond the Majapahit general population in that period. Besides, Gayatri was also the only woman figure who initiated the idea of democracy for the people in Majapahit, even though the concept of democracy was not perfectly worked due to the political culture in that period. Gayatri has great desire to unite the nusantara since her discussion with her father, her teacher, Raden Wijaya, and Gajah Mada, despite her gender. Gayatri, on the other hand has been proven that women at that time who had been subordinated to the imperial system, managed to break the rigidity of history, and prove that women are also capable to contribute to the improvement of kingdom's development and royal history. Behind Gajah Mada oath, Palapa there is the figure of Gayatri as a teacher who teach him about dignity. Behind the competence of Tribhuwana Tunggadewi and Hayam Wuruk in governing the kingdom, there was Gayatri who had been keeping harmonious kingdom and the people, behind the golden era of Majapahit kingdom.

\section{Acknowledgement}

We would like to thank everyone that has helped us to finish this paper. We would like to thank all of the lecturers and academic staff in Department of Politics and Government that have supported us morally as well as materially. We especially would like to thank Mama Rita that has helped us in funding so that we could go to 
Thailand and join this conference. For our family that always have our back. Also for Mrs. Yaya and Mrs. Mimi that have helped us in searching primary and secondary data through Majapahit books collection and history books about Majapahit in Mandala Majapahit from Yayasan Arsari Djojohadikusumo (YAD) in Faculty of Humanities Universitas Gadjah Mada. We would also thank all of the sponsors that have helped us in accommodation.

\section{References}

[1] Anderson, Benedict. Imagined communities: Reflections on the origin and spread of nationalism. Verso Books, 2006.

[2] Coedes, G. 2010. “Asia Tenggara masa Hindu-Buddha.” Jakarta: KPG.

[3] Djafar, H. 2009. "Masa Akhir Majapahit: Girindrawarddhana dan Masalahnya”. Jakarta: Komunitas Bambu.

[4] Drake, E. 2012. "Gayatri Rajapatni: Perempuan di balik Kejayaan Majapahit”. Yogyakarta: Penerbit Ombak.

[5] Easton, David. The political system. New York: Knopf, 1953.

[6] Kristinah, Endang, and Aris Soviyani. "Mutiara-Mutiara Majapahit." (2007).

[7] Pararaton: Teks bahasa Kawi. Terdjemahan bahasa Indonesia. Taman Siswa, 1966.

[8] Pigeud, T. H. "Java in the Fourteenth Century: Study in Cultural History. The Negarakertagama by Rakawi Prapanca of Majapahit." (1960). https://doi.org/10.1007/978-94-011-8774-9

[9] Schmitter, Philippe C., and Terry Lynn Karl. "What democracy is... and is not." Journal of democracy 2.3 (1991) 